\title{
Assessment of daleh swidden agriculture as an innovative alternative to conventional swidden under conditions of external pressure on local forest management in Kalimantan, Indonesia
}

\author{
NDAN IMANG ${ }^{1, \boldsymbol{}}$, RUJEHAN $^{2, v \downarrow}$, NELLA NAOMI DUAKAJU ${ }^{1}$ \\ ${ }^{1}$ Faculty of Agriculture, Universitas Mulawarman. Jl. Ki Hajar Dewantara, Gunung Kelua, Samarinda 75123, East Kalimantan, Indonesia. \\ Tel.+62-541-201275, Fax.: 62-541-206407, `email: imang_ndan@yahoo.co.id \\ ${ }^{2}$ Faculty of Forestry, Universitas Mulawarman. Jl. Kuaro, Gunung Kelua, Samarinda Ulu, Samarinda 75119, East kalimantan, Indonesia. \\ Tel./fax.: +62-541-741033, "email: rujehan56@gmail.com
}

Manuscript received: 1 February 2018. Revision accepted: 18 April 2018.

\begin{abstract}
Imang N, Rujehan, Duakaju NN. 2018. Assessment of daleh swidden agriculture as an innovative alternative to conventional swidden under conditions of external pressure on local forest management in Kalimantan, Indonesia. Biodiversitas 19: 840-848. Swidden agriculture is still an important livelihood for millions of people in the tropics. In Kalimantan Island of Indonesia, swidden agriculture is currently facing many external pressures such as massive expansion of oil palm plantations, concession for industrial plantations, and non-availability of financial and political support from the government. The above external pressures which ignore local wisdom in forest and land management have reduced the land available for swidden agriculture. The external pressures, in turn, have shortened the cycle of swidden agriculture and decreased the productivity of swidden agriculture. The objectives of the present study are to assess socio-cultural and economic aspects of the innovative daleh agriculture as an alternative to conventional swidden agriculture under these conditions. The study was conducted in an indigenous Bahau Dayak community of East Kalimantan, Indonesia. Twenty swiddeners and 6 other key informants were interviewed for data collection. Research findings confirm that the expansion of oil palm plantations has ignored the wisdom in forest and land management, in general, and caused pressure on swidden agriculture, in particular. Under such pressures, daleh swidden agriculture may be effectively practiced because it can increase land productivity and is also culturally acceptable. Further, financial and facilitation support from district government is needed to improve the practice of swidden agriculture in the study area.
\end{abstract}

Keywords: Daleh swidden agriculture, Dayak people, Kalimantan

\section{INTRODUCTION}

Swidden agriculture or shifting cultivation, locally called ladang, is one of the traditional practices of forest and land management by people in the tropics and is suitable to social typology in which there is a high interdependence between people and the environment (Dove 1993; Colfer et al. 1997; Inoue 2000). Furthermore, Sardjono (1990) maintains that traditional forms of swidden agriculture reflect an optimum interrelation between the strategy to serve human needs and efforts to maintain ecological balance in tropical regions. These practices can be further improved through agroforestry technologies to adapt to local socio-economic dynamics and environmental changes. Conceptually, swidden agriculture has a close relationship with social forestry. Pasaribu (2007), Sardjono (2007), and Inoue and Kawai (2013) define social forestry as any conditions and efforts which intimately involve local people in forestry activities to ensure economic, ecological and social benefits, and simultaneously sustain the resources.

Dove (1988) and Inoue (1999) point out that the term 'shifting cultivation' is often taken to mean that the people are themselves 'shifting' or semi-nomadic, even though most of them live in relatively permanent settlements. In fact, people use fire and fallow their field after harvest. The field, once set on fire, is called 'swidden'. So, 'swidden agriculture' is preferable to commonly used term 'shifting cultivation'.

Swidden agriculture is estimated to support 300-500 million people worldwide, covering about $30 \%$ of exploitable land for agricultural activities. In the Asia Pacific, swidden covers an area of 73 million hectares and, in Indonesia, it involves 35 million hectares of land and about 2.2 million cultivators (Mubyarto 1991).

Several scholars have studied swidden agriculture as practiced by the Kenyah Dayak people of East Kalimantan (Jessup 1992; Colfer et al. 1997; Sindju 2003). Inoue and Lahjie (1990) tried to develop models for the sustainability of Kenyah agricultural systems, including ladang. Sindju (2003), in a comparative study of ladang practiced by the Kenyah of West Kalimantan, Indonesia and the Kenyah of Sarawak, Malaysia, has qualitatively described the technological aspects of the practice.

Inoue (1999) categorized swidden agriculture in term of its sustainability as follows: (i) traditional swidden agriculture-sustainable swidden agriculture practiced by indigenous people, (ii) transitional (quasi-traditional) swidden agriculture-practiced by indigenous people, originating from both recurrent and pioneer types, but not so sustainable because of short fallow period, and (iii) nontraditional swidden agriculture-unsustainable slash and 
burn agriculture, often with cash crops, usually practiced by newcomers to village. $\square$

Though Swidden continue to play an important role in rural areas as indicated by the fact that around $65 \%$ of Mahakam Ulu people are still practicing swidden (BPS Mahakam Ulu 2016), the income from swidden agriculture was as low as Rp. 5-8 million (USD $385-615$ ) for one hectare (Pannalo 2015; Wijayanti 2016). Besides the low economic returns, conventional swidden agriculture is also under external pressures, such as expansion of oil palm cultivation, coal mining and industrial forests (Hutan Tanaman Industri = HTI) which reduce the extent of potential land available for swidden agriculture. Under these conditions, an innovative alternative to traditional swidden agriculture is desirable which is economically more productive and culturally more acceptable to local community.

The Dayak people have practiced swidden agriculture from many generations for subsistence and the indigenous Bahau Dayak have recently developed the practice of daleh swidden agriculture. Imang et al. (2004a) described that daleh is a concept initiated by the local Bahau Dayak in Matalibaq as the response to the disadvantages of conventional swidden and is culturally and economically more acceptable to people. In the present study, we have assessed the potential of this recently emerged practice of daleh agriculture as an alternative to the conventional swidden agriculture.

The specific objectives of the study are (i) to assess the traditional practices of land management under external and internal pressures on forest and land, (ii) to explore and compare the practices of conventional and daleh swidden agriculture and the associated problems, (iii) to assess socio-cultural and economic aspects of daleh swidden agriculture responsible for its successful implementation and cultural acceptance by the swiddeners, particularly the Dayak people.

\section{MATERIALS AND METHODS}

The present study was conducted in Matalibaq village, Long Hubung Sub-district, West Kutai District, East Kalimantan, Indonesia from July to August 2017. Data was gathered from indigenous Bahau Dayak community who lived here for over hundreds of years. The reasons behind choosing this village are: i) it has a long history of protecting and managing primary forest based on the cultural wisdom, ii) it has innovative local knowledge pertaining to the practice of more productive swidden agriculture, and iii) recently the village is facing the pressures of activities like oil palm plantation expansion, massive Industrial Forest expansion, and other types of forest and land degradation.

Data and information were collected through in-depth interviews with Customary Chief (Kepala Adat), Village Chief (Petinggi), former customary chief, five village elders and 20 swiddeners. Data and information collected pertain to the traditional wisdom and concept of managing forest and land, the concept and practices of conventional and daleh swidden system, their merits and demerits, threats and constraints and benefits involved.

\section{RESULTS AND DISCUSSION}

\section{Traditional knowledge-based forest and land management}

Matalibaq village territory covers an area of $88,000 \mathrm{~km}^{2}$ which was originally dominated by excellent primary forest. In order to protect the forest for sustainable local benefits, the available forest and land were allocated in 10 zones based on the availability of resources and sociocultural considerations. The forest and land zonations are as follows: (i) Tana' Umaq', land for settlement; (ii) Tana' Lumaq, areas for swidden agriculture, perennial and annual crops; (iii) Tana' Lepu'un Luma', the former swidden area that planted with fruits, in which the fruits are considered the proof of individual ownership; (iv) Tana 'Bio', forested customary land in which the customary head implemented strict rules so that nobody can utilize the forest area for any purpose; (v) Tana' Patai (kale'), space for cemetery; (vi) Tana' Berahan or Belahan, forested area for extraction of forest products such as timber for self consumption and for sale, hunting ground and fishing area; (vii) Tana' Mawa' protected forest area for collecting high value forest products such as resin, rattan, honey, timber for housing and boat making, eagle wood (gaharu)and forest fruits; (viii) Tana' Ang/Hang, the boundary area between adjacent villages wherein its utilization must be according to the agreement among bordering villages; (ix) Tana' Pukung, a protected forest area which is abundant in forest fruits for wild animals' as food; (x) Tana' Kaso, primary forest specially allocated for hunting because it is habitat for many wild animals such as wild pigs, deers and monkeys. People are strictly prohibited from disturbing the area that is allocated for breeding of wild animals because wild animal hunting is also a way of life of the community.

Such traditional land zonations persisted until external influences such as establishment of a logging company in 1992 and small-scale logging from 1999 to 2001 started affecting the village (Imang et al. 2004a). Such degradation activities have damaged forests outside the agricultural zone (tana' lumaq). The most massive forest and land degradation were caused by the land clearing for oil palm plantations taking place since 2014, covering around 6,000 hectares of land including primary forest area marked for hunting and fishing, without respecting the land zonation system followed traditionally by the villagers. Due to such destructive activities, some of the forest and land zones, such as those allocated for hunting and agricultural areas, have already been converted into oil palm plantations. Consequently, these activities have negatively impacted the practice of swidden agriculture. The most significant impact was a decrease in the land available for agriculture in general and swidden agriculture, in particular. This, in turn, shortened the cycle of conventional swidden agriculture. Under such a situation, the Bahau Dayak community of Matalibaq developed the concept of daleh swidden agriculture. 


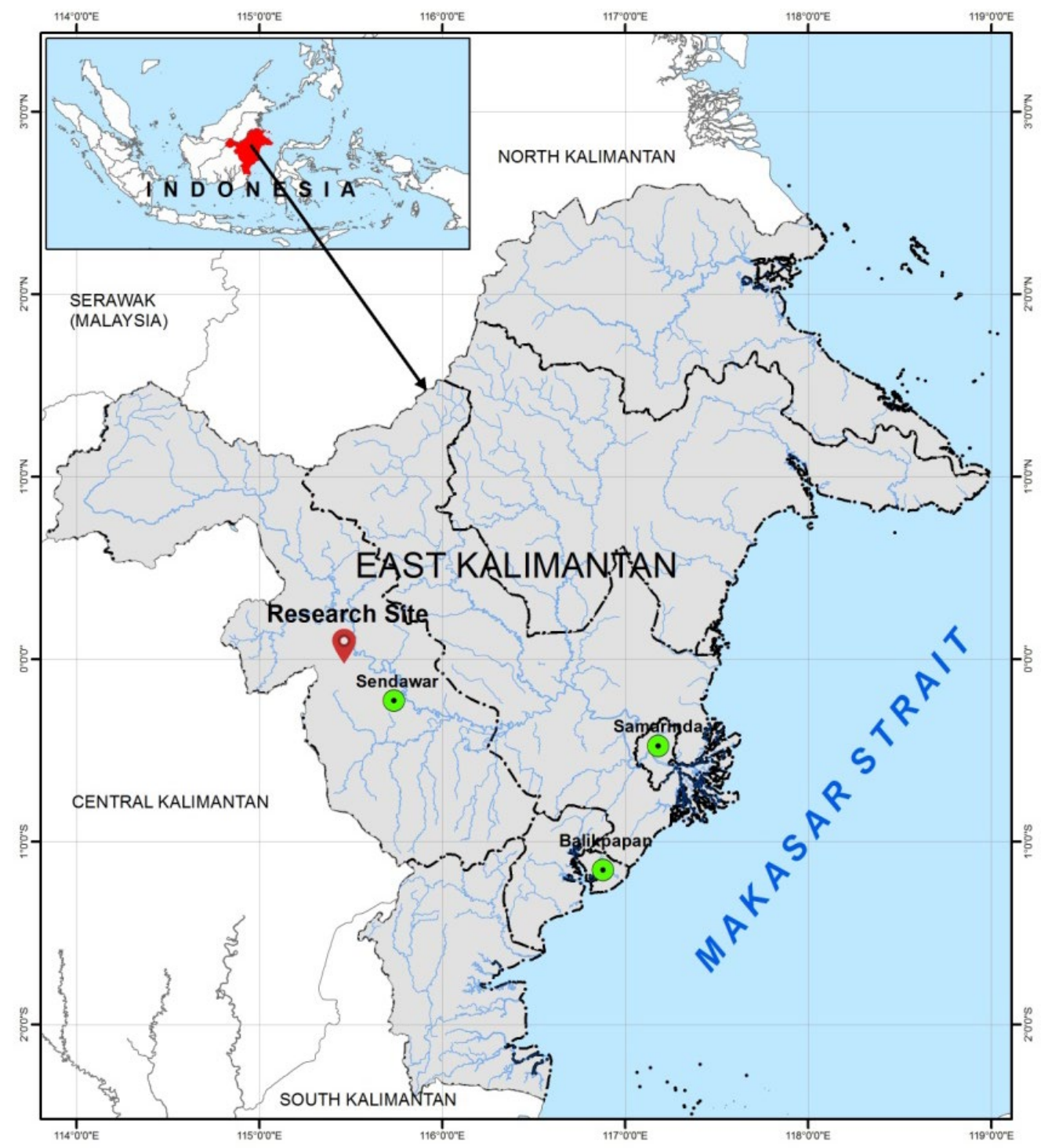

Figure 1. Map of the research site in Matalibaq village, West Kutai District, East Kalimantan, Indonesia

\section{The practice of conventional swidden agriculture}

Even though the practice of swidden agriculture is almost similar across countries, the local term in each country is different, e.g., tsheri or pangshingtsheri in Bhutan, milpa or tlacolol in Guatemala, Kaingin in Philippines, taungya in Thailand, si Nda Bot in Cameroon and in Indonesia, it is popularly known as ladang (Upadhyay 1995; Imang et al. 2004a). The local term for swidden agriculture in the research site of the present study is lumaq.

According to Imang (2004), the Kenyah Dayak people open new ladang through 9 stages. However, the Bahau Dayak people of Matalibaq village open their swidden agriculture commonly through 8 stages which are as follows: (i) slash the shrubs and small trees; (ii) cut down the big trees, which is usually a male-task because its risky for female; (iii) chop the fallen trunk for faster drying and proper burning; (iv) burn the vegetation which not only clears the ground for planting, but also releases nutrients from the biomass to increase the soil fertility; (v) planting preparation by removing the twigs; (vi) planting which is usually initiated by the Customary Chief (Kepala Adat) through a ritual ceremony to decide the most appropriate day for planting. Otherwise, the villagers believe that the harvests may not be good. This is an important stage of swidden in which the farmers gather and work together to plant one's swidden area in a labor exchange manner characterized by direct parity reciprocity; (vii) weeding, (viii) harvesting, like at planting stage, harvesting also a very joyful stage because the farmers will harvest together of 10 to 20 farmers and even more.

Swidden agriculture is still playing an important economic role in the study area. It is observed that more than $90 \%$ of the 156 households of the village are still practicing swidden agriculture. Each farmer has around 4-7 plots of land and the location of these plots are spread out with the distance between plots varying from 2 to 6 kilometers. The average size of the plots is 1.10 hectares 
and the mode of access to the plot or swidden field is either by foot/walk or by boat, and some farmers have recently started accessing the plots by motorbikes.

Productivity of swidden agriculture varies widely over the years, depending on the weather, rainfall, pests, and diseases. The average productivity per hectare in the study area in February 2017 was $1,475 \mathrm{~kg}$. The farmers feel that productivity was a bit lower than that of previous year of 2015 because of prolonged drought. Further, this productivity is lower than the swidden productivity of 1700 $\mathrm{kg}$ obtained in Pampang village which is around $650 \mathrm{~km}$ away from Matalibaq (Panalo 2015) and of Miau Baru village where it was $1,900 \mathrm{~kg}$ per hectare (Wijayanti 2016).

The farmers start swidden cultivation by clearing land in a randomly chosen location or plot, depending on how long the plot of land has been previously fallowed. The swidden plot for year-2 is located in the opposite direction away from swidden plot of yearl and the plots for subsequent years are selected in different locations. Consequently, the crops grown in previous years are mostly abandoned after moving to a new location for land clearing, for next years swidden. Farmers stay temporarily for 6 to12 months in one location, before moving to another location.

The more land a farmer has, the longer the swidden cycle and fallow period. Each plot of land is cleared in a rotation every year. The rotation of swidden locations is a strategy to allow the soil to regain its fertility through accumulation of biomass. The farmers have learnt by experience that the longer the swidden cycle, more fertile the soil becomes. The biomass from leaves and decomposed trees will be released to soil after it is burnt properly. This is in line with Weinstock and Sunito (1998) who mentioned that swidden agriculture is characterized by rotation of land rather than crops, or a rotational agriculture with a fallow period longer than the period of cultivation.

Farmers, through their experience, know that the rice planted in properly burnt area better growth compared to the rice planted in improperly burnt area. Properly burnt according to farmers is when leaves, twigs and small branches are completely burnt so that soil looks black. Therefore, during land clearing, farmers prefer felling trees towards inside of the swidden area instead of outside. This is also a strategy to prevent spreading of the fire to nearby forest areas during the burning of the swidden land.

\section{The practices of daleh swidden agriculture}

The cultural background of the daleh swidden is gotong royong, the cultural-spirit of 10 to 50 even more farmers working together in the swidden field of a farmer, usually in the stages of planting or harvesting. The labor exchange in gotong royong is characterized by direct parity reciprocity. Though the spirit of daleh can be practiced at any of the stages of swidden agriculture starting from slashing to harvesting, but the stages of planting and harvesting are the most suitable stages for gotong-royong.

The concept and steps of daleh swidden agriculture are as follows: (i) Daleh system consists of adjacent agriculture fields belonging to at least 4 households that are bordering each other, forming a cluster so that they can help each other whenever needed (Figure 3). (ii) Each household or farmer of the cluster should have at least one hectare of land, so that it can be divided into 4 plots, each measuring 0.25 hectares or more. One plot is cleared every year during the swidden cycle of 4 years (Figure 4). (iii) The huts or shelters of the all the minimum 4 swidden group members are located in the center of their swidden field in a proper location so that they can raise pig, chicken or fishes surrounding their huts. When any swidden group member leaves the swidden field for overnight stay at village/home, other group members take care of his/her pigs or chickens and protect them from predators. Pigs and chickens have played a very important socio-cultural role in the life of Bahau Dayak people for hundreds of years. They offer pigs and chickens as sacrifices in every village ceremony. Manure of this livestock used as fertilizer for farming. On the other hand, domestic and agricultural wastes/bye products are used to feed them.

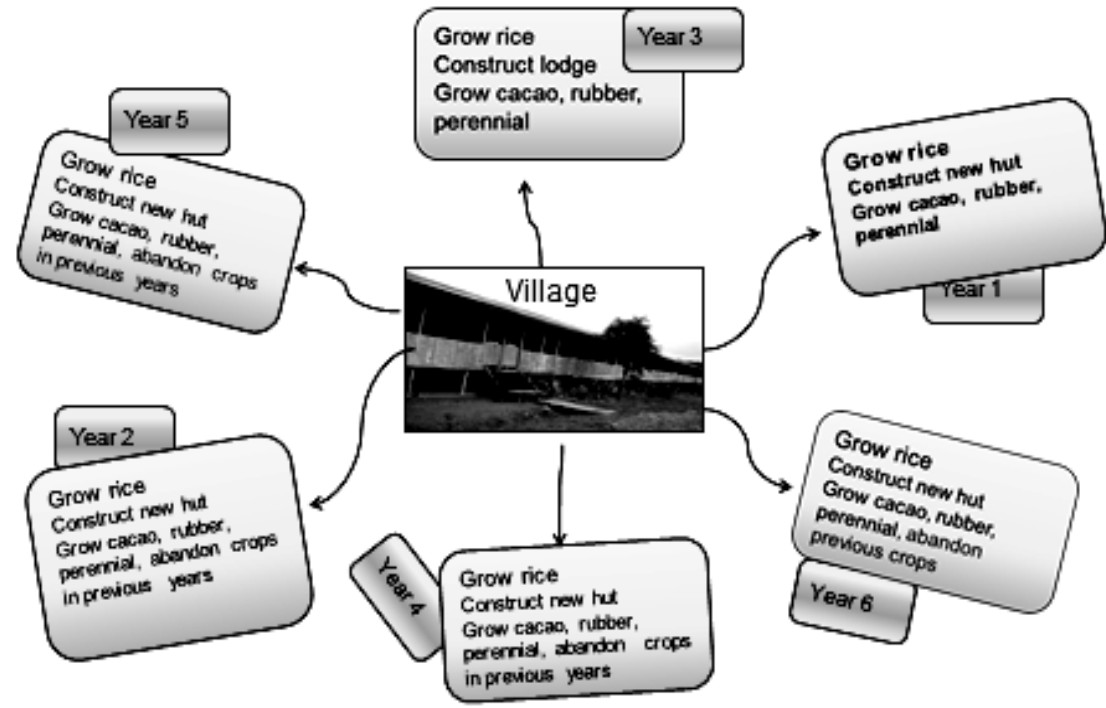

Figure 2. Utilization of land plots during different years in conventional swidden agriculture 
Table 1. Practices of conventional swidden agriculture of a 6-year cycle in the study area.

\begin{tabular}{|c|c|c|}
\hline Year & Activities & Harvested products \\
\hline 1 & $\begin{array}{l}\text { Open swidden agriculture and grow rice, build a small hut/shelter, grow some } \\
\text { vegetables and annual crops such as cacao, rubber or pepper. }\end{array}$ & Rice, corn, and vegetables. \\
\hline 2 & $\begin{array}{l}\text { Open swidden agriculture in another place/plot, develop new hut again and } \\
\text { other supporting facilities, growing vegetables, cacao, rubber or pepper. But, } \\
\text { they abandon crops planted in year-1. }\end{array}$ & Rice, corn, vegetables. \\
\hline 3 & $\begin{array}{l}\text { Open swidden agriculture in another place/plot, develop new hut again and } \\
\text { other supporting facilities, grow vegetables, cacao, rubber or pepper. But, they } \\
\text { abandon the crops planted in year- } 2 \text {. }\end{array}$ & Rice, corn, vegetables. \\
\hline 4 & $\begin{array}{l}\text { Open swidden agriculture in another place/plot, develop new hut again and } \\
\text { other supporting facilities, grow vegetables, cacao, rubber or pepper. But, they } \\
\text { abandon the crops planted in year-3. }\end{array}$ & Rice, corn, vegetables. \\
\hline 5 & $\begin{array}{l}\text { Open swidden agriculture in another place, develop new hut again and other } \\
\text { supporting facilities, grow vegetables, cacao, rubber or pepper. }\end{array}$ & $\begin{array}{l}\text { Harvest rice, corn, vegetables. Cacao, } \\
\text { rubber or pepper not harvested because } \\
\text { they were abandoned }\end{array}$ \\
\hline 6 & $\begin{array}{l}\text { Open swidden agriculture in another place, develop new hut again and other } \\
\text { supporting facilities, grow vegetables, cacao, rubber or pepper. }\end{array}$ & $\begin{array}{l}\text { Harvest rice, corn, vegetables. Cacao, } \\
\text { rubber or pepper not harvested because } \\
\text { they were not maintained well. }\end{array}$ \\
\hline 7 & $\begin{array}{l}\text { Return to the plot of year-1, and start all steps of swidden from the beginning. } \\
\text { The crops they planted in previous years not grow well because they } \\
\text { abandoned. }\end{array}$ & $\begin{array}{l}\text { Cacao, rubber or pepper not harvested } \\
\text { because they were not maintained well. }\end{array}$ \\
\hline
\end{tabular}

Table 2. The disadvantages of conventional swidden agriculture as observed in the study area

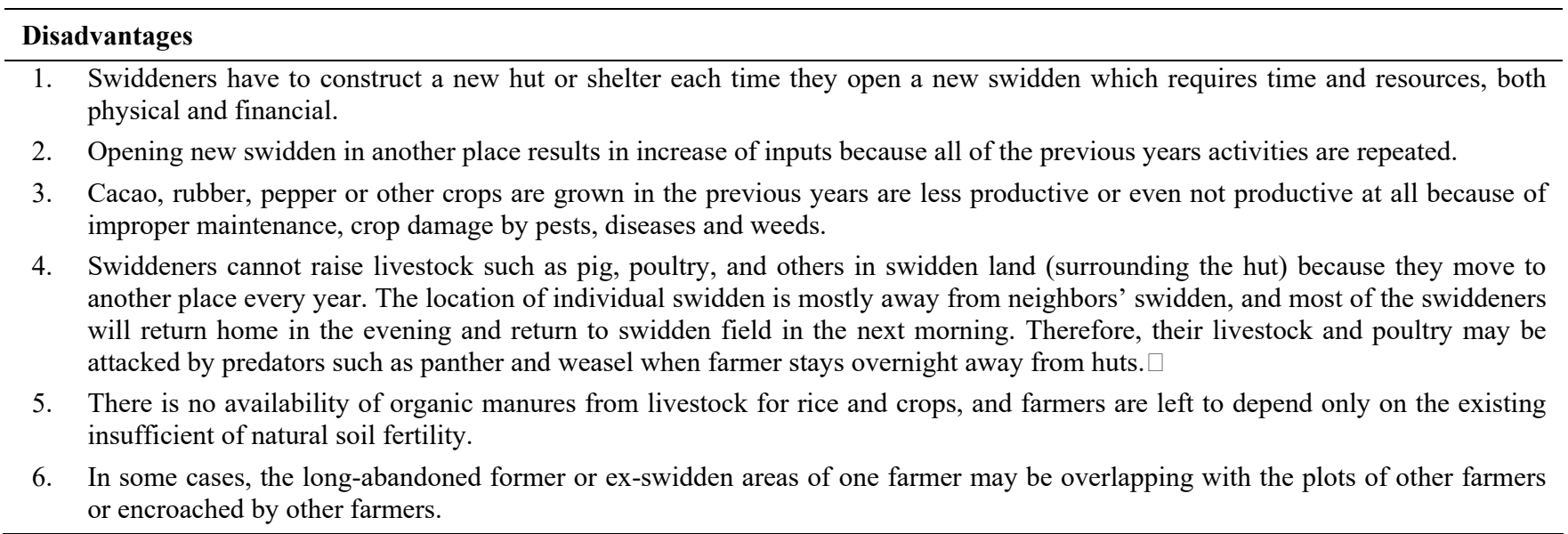

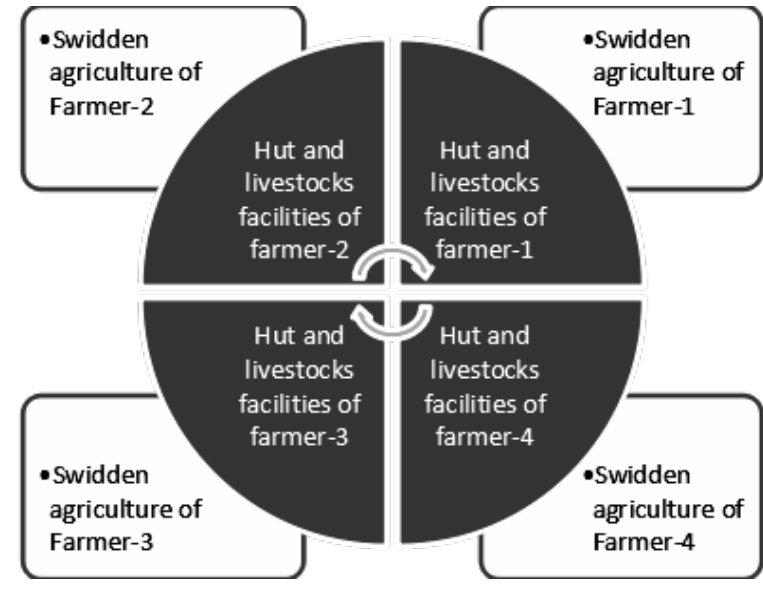

Figure 3. A cluster of daleh swidden agriculture consisting of four farmers
Firstly, the farmer divided the land into some smaller plots. The number of plot depends on the size of land or depending on how large of land can be cleared by farmer, usually 4-6 plots. In this part, we use a case of 6 plots, while in Table 3 below is a case of 4 plots. Secondly, farmer will clear one plot every year from year- 1 to year- 6 in the same way and also similar crops. (i) In the first year, the swiddener cleared plot-1 and grew rice, corn, cucumber, vegetables at the same time. After six months, the rice could be ready to harvest. After the 0.25 ha of swidden already harvested, the swiddener can grow cacao, rubber, vegetables in former of the swidden field. (ii) In the second year, it is the turn for the second plot or plot-2 to clear for swidden in the same way and similar crops with the plot-1 in year-1. At the same time, the swiddener can maintain the crops he/she planted in the previous year so that the crops grow well. (iii) In the next year- 3 and year- 4 , 
the swiddener also repeat the same ways as in the previous years until all of the 4 plots completed to clear for rice and other crops. In year-4, the one-hectare of land is already planted with some annual and perennial crops, and ready to harvest. (iv) In year-5, the swiddener can move to other nearby area to open new swidden while also maintaining the crops in the previous years and raising livestock. Cacao and rubber or other crops are ready to harvest in year- 5 or year-6.

Figure 4 shows the details of how a farmer allocates his/her land during daleh swidden agriculture. The hut or shelter is built only once in the first year. They also build other facilities like cages to raise livestock either in year 1 or year 2. These huts and cages built once last for more than 5 years because of which farmers save time, labor, and economic and material resources otherwise spent every year for these works. Further details such as the pattern of plot clearing, crops grown, animals raised and products harvested in the practice of daleh swidden agriculture are shown in Table 3.

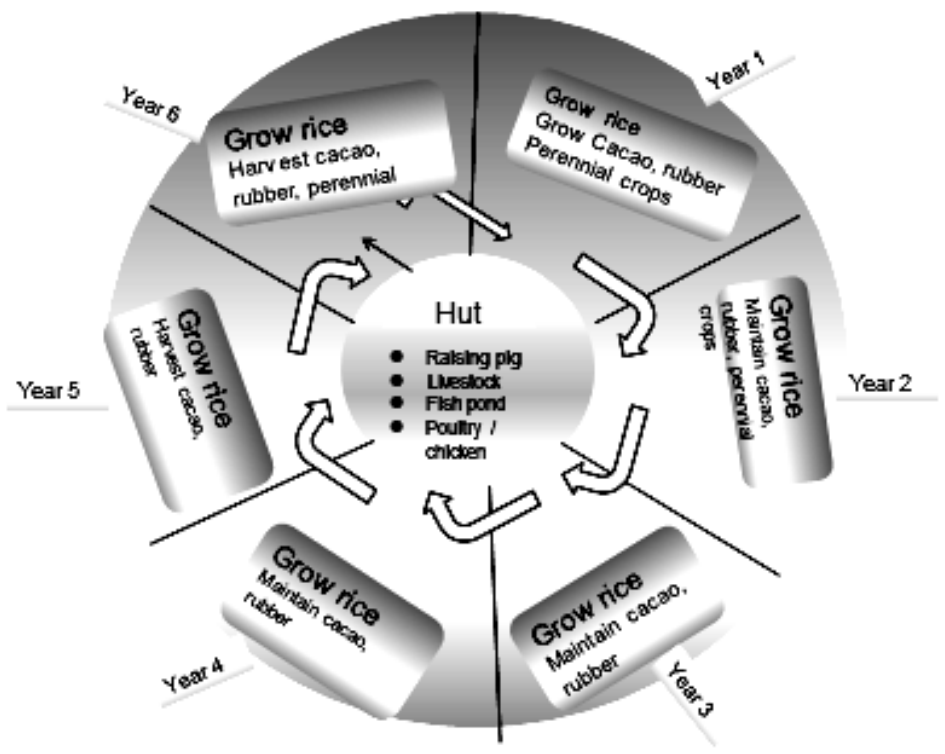

Figure 4. Details of utilization of one-hectare land in daleh swidden agriculture practice

Table 3. Practices of daleh swidden system in 4 plots of land

\begin{tabular}{ll}
\hline Year & Daleh swidden agriculture practices \\
\hline 1 & Plot-1 is cleared for swidden to grow rice, corn, and vegetables at the same \\
& time. Swiddener also builds a proper hut/shelter. While waiting for the \\
& harvest of rice, swiddener prepares cage for pig and poultry. After rice \\
& harvesting, the farmer grows rubber, cacao and/or other annual and perennial \\
& crops in the former swidden field Just after the rice is harvested.
\end{tabular}

2 Plot-2 is cleared to grow rice, cucumber, corn, vegetables at the same time. No need to build a new hut/shelter. Swiddener continues to raise pig and poultry or fish pond. After rice harvesting, the farmer grows rubber, cacao and/or other annual and perennial crops in the former swidden field.

3 Plot-3 is cleared for swidden to grow rice, corn, and vegetables at the same time. Swiddener also builds a proper hut/shelter in the year-1. While waiting for the rice to harvest, swiddener prepares cage for pig and poultry. After rice harvesting, the farmer grows rubber, cacao and or other annual and perennial crops in the former swidden field after rice is harvested..

$4 \quad$ Plot-4 is cleared for swidden and after rice harvesting, swiddener grow cacao, rubber or pepper or other annual and perennial crops. In parallel, the swiddener also maintain crops they planted in plot-1 to 3 .

\section{Harvested products}

Rice, corn, cucumber, vegetables, chicken.

Rice, corn, cucumber, vegetables, chicken, pig, fishes. In parallel, they can also maintain crops planted in previous years, and raise livestock such as chicken or pig.

Harvest rice, corn, vegetables, chicken, pig, fishes. In parallel they can also maintain crops they planted in previous years, and raise livestock such as chicken.

Harvest rice, corn, cucumber, vegetables, chicken, pig, fishes. In parallel, they can also maintain crops they planted in previous years, and keep to raise livestock $\square$

Cacao and rubber they planted in year-1 plot-1 ready to for harvest, while they also maintain the crops they planted in year- 2 to year-4. They also benefit from the livestock. 
Economic comparison between conventional and daleh swidden agriculture

Table 4 summarizes the economic comparison between conventional and daleh agriculture in terms of the various activities involved and products harvested. It is evident from the table that both systems have the same activities such as growing $(\mathrm{G})$, maintaining $(\mathrm{M})$ and harvesting products $(\mathrm{P})$ such as rice, corn, and vegetables.

The differences are observed from second year onwards, the notable ones are: (i) The crops grown in previous years, excluding rice, are maintained in daleh system because the subsequent years plots are close to the first year's plot. However, they are abandoned or neglected in conventional swidden agriculture due to the distance between first year's plot and subsequent years plots. (ii) In conventional swidden agriculture, farmers do not build cages or facilities to raise chicken/poultry or pig and other livestocks because they live at the swidden site only for about 6 months to a year. After harvesting rice, they move to another swidden plot located far away from the first one. But in daleh, livestock is maintained as they live in the same location throughout the swidden cycle.

As mentioned above, the daleh swidden is a multi-product agricultural system as it involves mutual symbiosis between different elements such as rice, crops (cacao, rubber, pepper), livestock and fish. In this system, products or bye products of one element supports or sustains the other elements and this enhances the overall productivity of the whole system. For example, the waste products resulting from rice cultivation is utilized to feed poultry and pig, while the manure of poultry and pig is used as organic fertilizer for crops. The central element of daleh system is the farmer and his/her family who control and maintain all elements, and at the same time, get multiple benefits from rice, other crops, and livestock. Figure 5 shows the multifarious interactions among the different elements of a daleh swidden agriculture system.

Table 4. Economic comparison between conventional swidden and daleh swidden systems of agriculture

\begin{tabular}{|c|c|c|c|c|c|c|c|c|c|c|c|}
\hline \multirow[t]{2}{*}{ Crops } & \multicolumn{5}{|c|}{$\begin{array}{c}\text { Conventional swidden } \\
\text { Year }\end{array}$} & \multicolumn{6}{|c|}{$\begin{array}{c}\text { Daleh swidden system } \\
\text { Year }\end{array}$} \\
\hline & 1 & 2 & 3 & 4 & 5 & 1 & 2 & 3 & 4 & 5 & 6 \\
\hline Rice & GMP & GMP & GMP & GMP & GMP & GMP & GMP & GMP & GMP & GMP & GMP \\
\hline Rubber & GM & A & A & A & AP- & GM & GM & GM & GM & GMP & GMP \\
\hline Cacao & GM & A & A & A & AP- & GM & GM & GM & GM & GM & GMP \\
\hline Banana & GM & P- & P- & P- & $\mathrm{P}-$ & GM & MP & MP & MP & MP & MP \\
\hline Chicken & GMP & 0 & 0 & 0 & 0 & GMP & GMP & GMP & GMP & GMP & GMP \\
\hline Pig & 0 & 0 & 0 & 0 & 0 & GM & GMP & GMP & GMP & GMP & GMP \\
\hline Vegetables & GMP & GMP & 0 & 0 & 0 & GMP & GMP & GMP & GMP & GMP & GMP \\
\hline Manure & 0 & 0 & 0 & 0 & 0 & $\mathrm{P}$ & $\mathrm{P}$ & $\mathrm{P}$ & $\mathrm{P}$ & $\mathrm{P}$ & $\mathrm{P}$ \\
\hline
\end{tabular}

Note: G: Grow/ raise livestock and/or poultry, M: Maintain the crops, A: Abandoned/not properly maintained, P: Production of crops, or manure of livestock, P-: Production but less, F: Fail, no production because the crops are abandoned, O: No agricultural activity/no raising of livestock $\square$

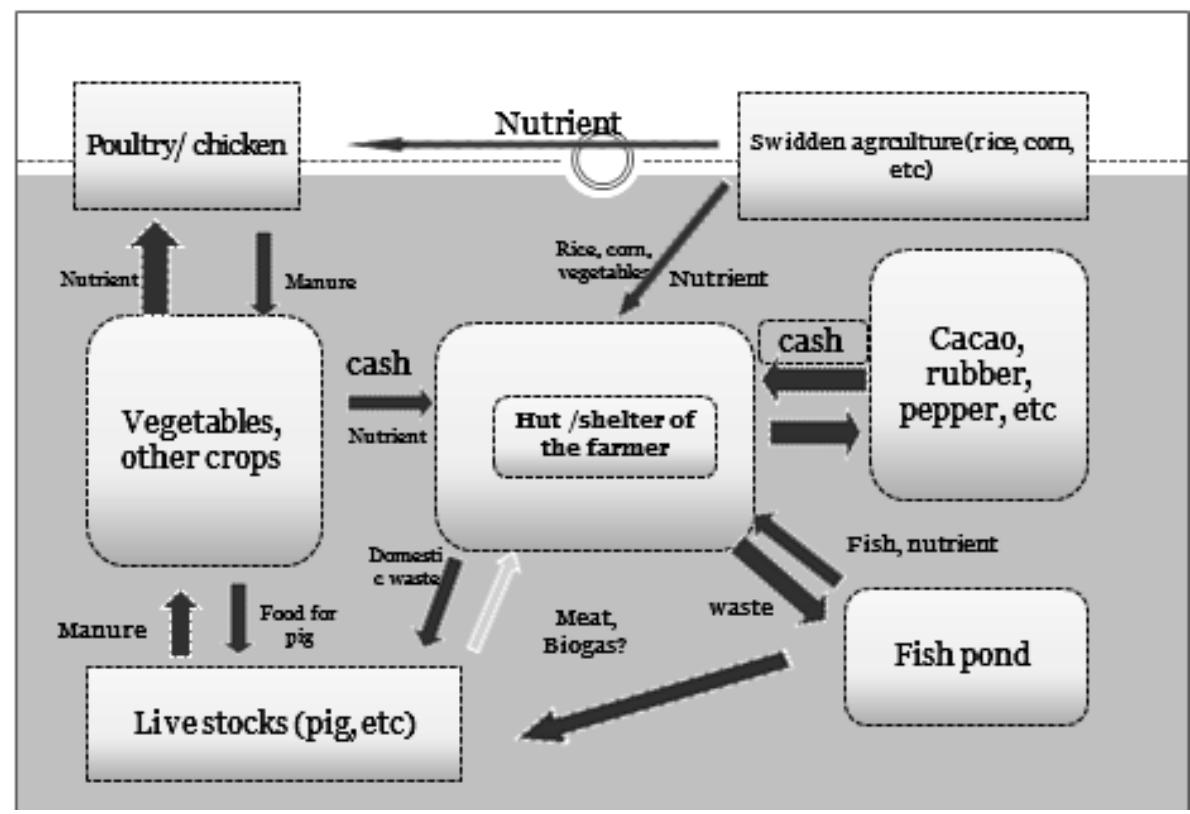

Figure 5. Interactions between different elements in a daleh swidden agriculture system 
Table 5. Constraints and threats to swidden agriculture in the study area

\begin{tabular}{|c|c|c|}
\hline No & Constraints/ threats & Remarks \\
\hline 1 & $\begin{array}{l}\text { Expansion of oil palm plantations and Industrial Forests }(H T I) \\
\text { that caused the conversion of agricultural lands to commercial } \\
\text { plantations }\end{array}$ & $\begin{array}{l}\text { Some of the fertile land zones such as Tana' berahan, } \\
\text { Tana' Kaso dan and Tana' Mawa' have been converted } \\
\text { to oil palm plantations and man-made tree forests }(H T I) \text {. }\end{array}$ \\
\hline 2 & $\begin{array}{l}\text { The division of land into smaller plots so that it is more difficult } \\
\text { to practice daleh swidden agriculture. }\end{array}$ & $\begin{array}{l}\text { A cluster of daleh system needs at least } 4 \text { to } 6 \text { hectares } \\
\text { of land for its effective practice and a sufficient land } \\
\text { fallow. }\end{array}$ \\
\hline 3 & $\begin{array}{l}\text { The decreasing interest of young generation towards farm work } \\
\text { because of reasons such as hard manual labor involved, low } \\
\text { income which is insufficient to fulfill their daily needs of } \\
\text { subsistence and monetary requirement, uncertain market for } \\
\text { agricultural products, etc. }\end{array}$ & $\begin{array}{l}\text { Panalo (2016) found that average output of one hectare } \\
\text { of swidden agriculture is Rp. } 8.6 \text { million. It means that } \\
\text { the average income for one month is Rp. } 1.1 \text { million }\end{array}$ \\
\hline 4 & $\begin{array}{l}\text { Technological innovations in the area of swidden agriculture are } \\
\text { lacking when compared to wet rice cultivation. Therefore, all } \\
\text { stages of swidden activities are done manually which is also a } \\
\text { reason for its low productivity. }\end{array}$ & $\begin{array}{l}\text { The remote location of the swidden agriculture also a } \\
\text { constraint for agricultural officers to develop } \\
\text { agricultural activities. }\end{array}$ \\
\hline 5 & $\begin{array}{l}\text { There are no schemes of financial support to develop swidden } \\
\text { agriculture compared to wetland rice which gets financial } \\
\text { support for development }\end{array}$ & $\begin{array}{l}\text { Financial support provided to wetland rice, whereas } \\
\text { farmers preference is towards swidden agriculture. }\end{array}$ \\
\hline 6 & $\begin{array}{l}\text { The emerging negative perception about swidden farmers who } \\
\text { clear land using fire which is also blamed as a cause for forest } \\
\text { fire. }\end{array}$ & $\begin{array}{l}\text { There is a West Kutai District Regulation (Peraturan } \\
\text { Daerah = PERDA) prohibiting the use of fire for land } \\
\text { clearing. In this case, government did not consider the } \\
\text { wisdom and culture of swidden agriculture. }\end{array}$ \\
\hline
\end{tabular}

\section{Threats to swidden agriculture}

The basic principle of shifting cultivation or swidden agriculture is the availability of sufficient time gap for the fallowed lands to regain their natural fertility, between successive swidden cycles. The usual duration of one cycle varies from 5 to 10 years, depending on the fertility of the land/soil and other considerations of the farmers. This implies that a farmer should have at least 5 plots of swidden land to maintain this cycle by allowing enough time for the soil to become fertile after one swidden cultivation.

However, the expansion of oil palm plantation has decreased the availability of suitable land for swidden agriculture. The narrower the extent of land available for swidden, shorter the swidden cycle becomes. Shortening of swidden cycle to less than 5 years, in turn, decreases land productivity because of insufficient nutrients in soil. This is one of the major threats to the continued practice of swidden agriculture, particularly in the study area. There are also other threats and constraints to swidden agriculture in general which are summarized in Table 5.

\section{Conclusion}

The introduction and expansion of oil palm plantations, logging and industrial planted forests $(H T I)$ in the village territory ignored and did not recognize the traditional wisdom of forest and land management. These activities were granted concession by Provincial and District Government and Customary Institutions are not strong enough to protect their lands that are taken over by concessions such as oil palm or industrial forest. Swidden agriculture still plays an important role in the economic life of the community because more than $90 \%$ of the households still actively practicing swidden agriculture every year, despite its disadvantages. The pressures and threats to the continued existence of conventional swidden agriculture have necessitated an innovative alternative swidden method which can improve land productivity and generate better income for farmers. The daleh swidden agriculture, which is integrated swidden farming combining the traditional swidden agriculture with livestock and other crops in one plot, has the potential to become such an alternative because it improves land productivity, increases return to farmers, and more importantly, it is culturally acceptable to the community. Unfortunately, District Government is not providing any financial assistance and agri-technological support to organize farmers for practicing more productive swidden agriculture.

In order to protect the agriculturally potential land for the purpose of swidden, the government should recognize the local wisdom on forest and land management and should consider providing financial and facilitation support for the practice and improvisation of both conventional and daleh systems. Besides the economic benefits of swidden agriculture, the Bahau community also of the opinion that the daleh swidden agriculture may also become an "agricultural tourism object" in the future, particularly at its two most important stages of planting and harvesting. 


\section{ACKNOWLEDGMENTS}

The authors gratefully acknowledge the financial support from Islamic Development Bank/IDB through the University of Mulawarman that enabled them to undertake this research. Special thanks and acknowledgments are due to the Village Chief (Petinggi), Customary Chief (Kepala Adat) and the people of Matalibaq village who voluntarily shared their valuable experiences and expectations during the field observations. We also appreciate perspective comments and constructive critiques from anonymous reviewers of this manuscript.

\section{REFERENCES}

BPS Mahulu. 2016. Badan Pusat Statistik Kabupaten Mahakam Ulu. Mahakam Ulu, East Kalimantan. [Indonesian].

Colfer C, Peluso N, Chung C.S. 1997. Beyond Slash and Burn. Building on Indigenous Management of Borneo Tropical Rainforest. N.Y. Botanical Garden, New York.

Dove M.. 1993. Uncertainty, humility, and adaptation in the tropica forest: The agricultural augury of the Kantu. Ethnology 40: 145-167.

Dove MR. 1988. Sistem Perladangan di Indonesia. Suatu Studi Kasus dari Kalimantan Barat. Gajah Mada University Press, Yogyakarta. [Indonesian].

Imang N. 2004. From Shifting Cultivation Towards Daleh Cluster: A Case from the Bahau Dayak People. LIPI, Jakarta

Imang N, Gani A, Yokota Y, Saito T, Mochizuki A. 2004a. Forest Management and Community Participation in Batu Majang. Local People in Forest Management and the Politic of Participation. Nanang M, Devung GS (eds.). Indonesia Country Report. IGES, Kanagawa Japan.

Imang N, Gani A, Yokota Y, Saito T, Mochizuki A. 2004b. Forest management and Community Participation in Mata Libaq. In: Nanang M, Devung G.S. (eds.). Indonesia Country Reports: Local People in the Forest Management and the Politics of Participation. IGES, Kanagawa, Japan.

Inoue M, Kawai M. 2013. Implications of local peoples' references in terms of income source and land use for Indonesia's national REDD- plus policy: evidence in East Kalimantan, Indonesia International J Environ Sustain Dev 12 (3): 244-263.

Inoue M, Lahjie AM. 1990. Dynamics of swidden agriculture in East Kalimantan. Agrofor Syst 12: 269-284.

Inoue M. 1999. Evaluation of local resources management systems as the premise for introducing participatory forest management. J For Econ 44 (3): 15-22.

Inoue M. 2000. Mechanism of changes in the Kenyah's swidden system: Explanation in terms of agricultural intensification theory. Ecological Studies 140. In: Guhardja E, Fatawi M, Sutisna M, Mori T, Ohta S (eds.). Rainforest Ecosystems of East Kalimantan. Springer, Tokyo.

Jessup TC. 1992. Persistence and change in the practice of shifting cultivation in the Apo Kayan, East Kalimantan, Indonesia. In: Fox JJ (eds.). The Heritage of Traditional Agriculture among the Western Austronesians. Australian National University, Canberra, Australia.

Mubyarto. 1991. Desa-Desa di Perbatasan Kalimantan Timur. Kajian Sosial Ekonomi. Aditya Media, Yogyakarta. [Indonesian].

Pannalo M. 2016. Analisis Usahatani Padi Ladang dan Dinamika Pemanfaatan Lahan di Kelurahan Budaya Pampang Kecamatan Samarinda Utara. Universitas Mulawarman, Samarinda. [Indonesian].

Pasaribu HS. 2007. Kehutanan Sosial. Litbang Kehutanan, Departemen Kehutanan RI, Jakarta. [Indonesian].

Sardjono MA. 1990. Die Lembo-Kultur in Ostkalimantan. Ein Model fuer die Entwicklung agroforstlicher Landnutzung in der Feucttroppen (Dissertation). Hamburg Universitat, Germany.

Sardjono MA. 2007. Agroforestry: An Appropriate Technology of Social Forestry to Revitalize Local Wisdom towards Community Empowerment in Indonesia. Faculty of Forestry/Center for Social Forestry, Universitas Mulawarman, Samarinda. [Indonesian].

Sindju HB. 2003. Making a swidden: Social and technological aspects of Lepo'ke agricultural practice. Eghenter E, Sellato B, Devung GS (eds.). Social Science Research and Conservation Management in the Interior of Borneo: Unravelling Past and Present Interaction of People and Forests. CIFOR, Bogor.

Upadhyay KP. 1995. Shifting Cultivation in Bhutan: A Gradual Approach to Modifying Land Use Patterns. FAO-UN, Rome.

Weinstock JA, Sunito S. 1998. Review of Shifting Cultivation in Indonesia. Directorate General of Forest Utilization, Ministry of Forestry, Government of Indonesia and FAO, Jakarta.

Wijayanti. 2016. Analisis Usahatani Padi Ladang dan Dinamika Pemanfaatan Lahan di Desa Miau Baru, Kecamatan Kongbeng, Kabupaten Kutai Timur. Universitas Mulawarman, Samarinda. [Indonesian]. 